\title{
Effect of sulphur added to phosphate rock on solubility and phytoavailability of phosphorus
}

\author{
Ewa Stanisławska-Glubiak ${ }^{1 *}$, Jolanta Korzeniowska ${ }^{1}$, Józef Hoffmann², Helena Górecka ${ }^{2}$, \\ Wiktor Jóźwiak ${ }^{3}$, Grażyna Wiśniewska ${ }^{3}$ \\ ${ }^{1}$ Institute of Soil Science and Plant Cultivation - State Research Institute \\ ${ }^{2}$ Wrocław University of Technology \\ ${ }^{3}$ INCO-VERITAS S.A. \\ "Corresponding author: e-mail: e.glubiak@iung.wroclaw.pl
}

\begin{abstract}
For ground phosphate rock (GPR) to be applied as phosphorus fertilizer, the availability of phosphorus to plants needs to be improved. One possible way to achieve this is by adding sulphur, which will accelerate decomposition of phosphate in soil owing to the activation of microbiological processes. This study involved granulation of fertilizers composed of phosphate and sulphur mixed at 38:1 and 10:1 ratios and two analogous fertilizer variants but with added molasses as a source of organic carbon for sulphur bacteria. A small-scale industrial installation for production of multi-component fertilizers was used to make granular fertilizer by the compaction method. The granular fertilizers were then tested in an agricultural experiment. The fertilizer in which the phosphate to sulphur ratio was 10:1 produced better effects. Addition of molasses to the fertilizers did not improve their fertilizing capacity.
\end{abstract}

Keywords: phosphate and sulphur fertilizers, granulation, compaction, phosphate solubility, phosphate bioavailability.

\section{INTRODUCTION}

Production of concentrated phosphate fertilizers known as superphosphates entails technological processes in which the raw material such as phosphate rock (PR) undergoes very expensive chemical processing. Economic considerations alongside environment protection requirements encourage us to look for less expensive and waste-free technologies for manufacture of phosphate fertilizers, which ensure an adequate quantity and quality food production output. More attention is now attached to possible agricultural use of ground phosphate rock (GPR) without any or with little chemical processing ${ }^{1-5}$. However, it needs to be remembered that natural phosphate rock is much less effective than superphosphate, in which phosphorus appears as easily soluble compounds. When developing new fertilizer manufacturing technologies based on the use of phosphate rock, it is important to raise the content of readily soluble forms of phosphorus. This can be achieved, for example, through an addition of sulphur to GPR ${ }^{6-10}$. Phosphate rock and sulphur fertilizer (PRSF) with an adequate ground phosphate rock to sulphur ratio (GPR:S) is metabolized in soil owing to activation of microbiological processes. Soil-borne sulphur bacteria oxidize sulphur to sulphuric acid, which reacts with molecules of phosphate rock, generating soluble mono- and di-calcium phosphates. The factors affecting the effectiveness of such fertilizers are: the quality of phosphate rock, the degree of its milling, ratio of GPR: S, and the type of crops and soil. The presumption is that the increase of sulphur will increase their agronomic effectiveness.

Most of the studies concerning the effectiveness of PRSF were carried out in much warmer and wetter climatic zone than the

temperature which prevails in Poland. These studies have shown that PRSF can be as efficient as superphosphate when the ratio of GPR: S oscillates between 1: 1 and 5: 1, and at increasing the degree of crushing rock phosphate, it may be increased to $7: 1^{6}$.
However, it should be taken into account that along with the phosphorus, sulphur is also introduced into the soil, which in addition to reaction with molecules of phosphate rock, has an acidifying effect on the soil. Therefore, the quantity of added sulphur should be minimized so as not to cause an additional acidification of the soil?.

Another way of increasing phosphate rock solubility is by composting it with organic matter. Products of the metabolism of microorganisms which decompose organic matter break down phosphate, releasing plant available phosphate compounds. A ratio of four parts of organic waste material to one part of phosphate rock seems to be an effective combination. The addition of molasses as a source of carbon for sulphur bacteria enhanced $\mathrm{P}$ solubility by a few percent ${ }^{11}$.

The aim of our study was to compare the fertilizing efficiency of several variants of PRSF with different ratio of phosphate rock to sulphur with the addition of molasses or without its participation. Another goal has been to select the best pelletization technology for such fertilizer.

\section{MATERIAL AND METHODS}

\section{Laboratory tests}

Several variants of PRSF were made from phosphate rock originating from Morocco and obtained from Phosphate Fertilizer Production Plant in Gdańsk and ground sulphur produced by the Siarkopol Chemical Plant.

In the Laboratory of the Institute of Inorganic Technology and Mineral Fertilizers, at Wroclaw University of Technology, certified by ILAC-MRA and Polish Centre of Accreditation (certificate No. AB 696), grain-size distribution of both raw materials was assessed by passing a specific amount of each material through a set of sieves with the mass of each mesh fraction weighed afterwards $^{12,13}$. The results are presented in Table 1 . Ground sulphur was characterized by the grain size that enabled its proper mixing with the GPR. The plus mesh fraction 
Table 1. Sieve analysis of phosphate rock used for making PRSF

\begin{tabular}{|c|c|}
\hline Mesh size $(\mathrm{mm})$ & Minus mesh fraction (\%) \\
\hline 0.160 & 87.20 \\
0.125 & 80.12 \\
0.063 & 55.00 \\
\hline
\end{tabular}

of sulphur on a $0.045 \mathrm{~mm}$ mesh size made up $1.65 \%$ of the total amount. In addition, chemical composition of phosphate rock was also determined (Table 2). Analyses of particular forms of phosphorus found in the GPR were performed according to the procedures specified in the Regulation (EC) No 2003/2003 of the European Parliament and of the Council of 13 October 2003 relating to fertilizers ${ }^{14}$. The following analyses were made on GPR: extraction of phosphorus compounds soluble in mineral acids (total phosphorus), soluble in $2 \%$ formic acid, soluble in $2 \%$ citric acid, soluble in $2 \%$ neutral ammonium citrate and soluble in water. Determination of the extracted phosphorus was carried out after precipitation in an acid medium in the form of quinoline phosphomolybdate.

Analysis of the elements in phosphate rock was made by ICP optical spectrophotometry after mineralization of samples in aqua regia and in a microwave oven at $1200^{\circ} \mathrm{C}$ according to procedure no. LA3b-012 ( $\mathrm{Al}, \mathrm{As}, \mathrm{Ni}, \mathrm{Pb}, \mathrm{Cd})$, LA3b-013 (Ca, Mg) and LA3b-014(B, Cr, Cu, Fe, Mn, $\mathrm{Mo}, \mathrm{Zn}$ ). Analysis of the content of $\mathrm{Hg}$ was completed by atomic absorption spectrometry with amalgamation technique according to procedure no. LA3b-012. In the prepared PRSF, the concentration of particular elements was determined with the same methods as applied to the raw materials. Grain-size distribution and mechanical resistance of fertilizer granules were examined in an ERWEKA apparatus. The results were obtained by submitting 25 randomly chosen granules of each fertilizer variant to measurements.

Table 2. Chemical composition of phosphate rock used for making PRSF

\begin{tabular}{|l|c|}
\hline Element & Content $(\%$ mass $)$ \\
\hline Total P in mineral acids & 13.38 \\
P soluble in 2 \% formic acid & 6.42 \\
$\mathrm{P}$ soluble in 2\% citric acid & 3.55 \\
$\mathrm{P}$ soluble in ammonium citrate $(\mathrm{pH} 7.0)$ & 1.48 \\
$\mathrm{P} \mathrm{soluble} \mathrm{in} \mathrm{water}$ & 0.048 \\
$\mathrm{Ca}$ & 40.20 \\
$\mathrm{Mg}$ & 0.30 \\
$\mathrm{Al}$ & 0.12 \\
$\mathrm{Fe}$ & 0.39 \\
\hline Element & Content $\left(\mathrm{mg}^{\circ \mathrm{kg}^{-1}}\right)$ \\
\hline $\mathrm{B}$ & 26.0 \\
$\mathrm{Cr}$ & 108.0 \\
$\mathrm{Cu}$ & 22.0 \\
$\mathrm{Mn}$ & 17.0 \\
$\mathrm{Mo}$ & 1.7 \\
$\mathrm{Zn}$ & 415.0 \\
$\mathrm{As}$ & 8.3 \\
$\mathrm{Cd}$ & 29.0 \\
$\mathrm{Hg}$ & 0.052 \\
$\mathrm{Ni}$ & 38.0 \\
$\mathrm{~Pb}$ & 5.9 \\
\hline
\end{tabular}

\section{Industrial tests}

Tests on possible granulation of mixtures of phosphate and sulphur were run on a small-scale installation used for the manufacture of multi-component granular fertilizers by compaction. The installation was located at the INCO Plant in Susz near Iława. It consisted of a weigh module, mixing unit, granulator and dryer. The experiments on the granulation of the tested fertilizer variants were run in two granulators: a pelleting press manufactured by Amandus Kahl GmbH type 38-780 and a laboratory roll press type 210/50 made by Sahut-Conveur. The weight ratio GPR:S for the production of fertilizers was set as 38:1 and 10:1. Selection of both ingredients in the fertilizers started with choosing the amount of phosphorus to be applied in field production. The ratio of rock phosphate to sulphur of 10: 1 was determined on the basis of previously conducted own research $^{15,16,17}$. However, due to the specificity of the Polish soil, most of which are acidified, it was decided to also test a mixture of 38: 1 with a much reduced share of sulphur.

It was assumed that molasses would be added as a source of carbon for sulphur bacteria and bentonite as the material facilitating the granulation of fertilizers.

\section{Agricultural tests}

The aim of the agricultural tests was to determine the phytoavailability of phosphorus from the prepared PRSF according to the yields of crops and content of phosphorus in harvested plants. A pot experiment on oat and a micro-plot experiment on maize were set up at the Experimental Station of the Institute of Soil Science and Plant Cultivation in Jelcz-Laskowice near Wroclaw. The experiments were designed according to complete randomization with 4 replications. The yield-stimulating effect of 4 variants of PRSF (F1, F1m, F2, F2m) was compared with that produced by triple superphosphate (TSP) and ground phosphate rock (GPR) relative to the control without phosphate or sulphur (0) and a treatment enriched with sulphur alone.

Oat was grown on slightly acid soil $(\mathrm{pH}=5.7)$ with a very low content of organic carbon $\left(\mathrm{C}_{\mathrm{org}}=0.80 \%\right)$. Maize was cultivated on neutral soil $(\mathrm{pH}=6.7)$, relatively abundant in organic carbon $\left(\mathrm{C}_{\text {org }}=3.19 \%\right)$. Both soils contained little phosphorus ( 24 and $32 \mathrm{mg}_{2} \mathrm{O}_{5} \cdot \mathrm{kg}^{-1}$ ). The tested fertilizers were introduced to soil in a rate of $1 \mathrm{~g} \mathrm{P} /$ pot $(9 \mathrm{~kg}$ of soil) under oat and $3.5 \mathrm{~g} \mathrm{P} / \mathrm{plot}$ $\left(0.5 \mathrm{~m}^{2}\right)$ under maize. The dose of phosphorus, which is usually applied under test plants in pot experiments, was doubled due to the expected weaker solubility of the tested fertilizers compared to the superphosphate. A single dose of $\mathrm{P}$ could turn out to be too small to ensure an optimum supply of plants in this component. In the microplot experiment, the recommended dose of phosphorus per hectare was calculated into euros on the area of $0.5 \mathrm{~m}^{2}$, and also doubled.

The treatment with elemental sulphur (S) was supplied with a sulphur rate equivalent to the amount of this element introduced to soil with the fertilizer F2.

Oat and maize were harvested in the full ripeness stage. Samples of oat grain and samples of maize ear leaf were taken for determination of their content of phosphorus and sulphur. These analyses were performed in an accredited laboratory of the Institute of Soil Science and Plant Cultivation, certified by Polish Centre of Accreditation (certificate no. AB 339). Concentrations of phosphorus in the plant material were determined after wet digestion (concentrated $\mathrm{H}_{2} \mathrm{SO}_{4}+$ perhydrol) by the flow spectrophotometric method according to 
procedure no. PB 48.1 Edition I:2002. The content of sulphur was determined by ICP method following the mineralization with $\mathrm{NaHCO}_{3}$ according to procedure no. PB 110.2 Edition I:2010.

The results on yields and concentrations of phosphorus and sulphur underwent analysis of variance. Tukey's test was applied to test the differences between the means. Statistical computations were aided by Statistica 6.0 PL software.

\section{RESULTS AND DISCUSSION}

As a result of preliminary test of fertilizers pelletization, optimal proportions of bentonite and mellasses were determined (Table 3). Being a source of organic carbon for sulphur bacteria, molasses also served as an adhesive substance. Pelletization of fertilizers on a roll press failed because the material subjected to pressing was excessively fragmented. A high amount of air arrested in the raw material while compacting was an obstacle to forming the granules with satisfactory mechanical resistance. The best results of granulation were achieved on a pelleting press at the moisture of the processed mixture equalled $13 \%$, the applied pressure reaching 60 bar and the granular fertilizer dried up at $90^{\circ} \mathrm{C}$ for 40 minutes. The content of moisture after their drying was $0.3 \%$. Granules of fertilizers F1 and F2 varied in terms of mechanical properties such as grain-size distribution and mechanical resistance (Table 4). Fertilizers with a lower share of sulphur (F1, F1m) generally had a smaller diameter of granules and by several times higher resistance to crushing compared to F2 and F2m. The addition of molasses to granular compound fertilizers caused a reduction in the resistance of granules only in the case of F2. The mechanical resistance of F2m was by about $40 \%$ lower compared to F2. Regarding F2 fertilizers, a substantial decrease in the mechanical resistance of granules was observed, most probably due to a higher ratio of $\mathrm{S}$ and inclusion of molasses. These products were also much more elastic (easily deformable by application of an external force), which may have been interpreted by a ERWEKA apparatus as a destructive force. Generally, the tested fertilizers were characterized by satisfactory physical parameters.

The mechanical resistance of F1 fertilizer granules compared to typical resistance of different types of fertilizers, including phosphorus ones, appears very good ${ }^{18}$.

The four variants of PRSF were only slightly different in the total content of nutrients (Table 5). The total phosphorus content in fertilizer granules ranged from $10.10-11.50 \% \mathrm{P}$, and the content of sulphur was within $2.5-8.5 \%$. The fertilizers also contained $32-34 \%$ of calcium. It has been found out that an addition of sulphur to phosphate did not cause any significant changes in the content of phosphorus compounds soluble in the tested extractants. However, the amount of soluble forms of phosphorus released from fertilizers introduced to soil is always higher than that found in soils laboratory trials ${ }^{19}$.

The agricultural experiment showed that plants fertilized with GPR did not respond to the treatment by producing higher yields in comparison to control treatment without $\mathrm{P}$. This finding demonstrates poor solubility of phosphorus compounds in GPR and worse availability of this element to plants. Lack of response of plants to P fertilization in the form of GPR has also been reported by other authors ${ }^{20}$.

The effectiveness of the 4 tested PRSF variants depended on the mutual ratios of fertilizer components, but was also modified by the soil conditions and species of the crop. On the slightly acid soil with a small content of organic carbon, a significantly higher oat grain yield was achieved in response to the F2 fertilizer compared to the GPR and F1 treatments (Fig. 1). However, the F2 fertilizer did not stimulate higher yields than triple superphosphate. The fact that F2 had a more beneficial effect on crop yields than GPR or F1 was confirmed by a higher concentration of phosphorus found in oat grain from that treatment (Fig. 2). At the same time, there were no significant differences in sulphur content between the treatments.

Table 3. Composition of PRSF prepared for granulation (\% mass)

\begin{tabular}{|c|c|c|c|c|}
\hline Type of fertilizer & Phopshate & Sulphur & Bentonite & Molasses \\
\hline $\mathrm{PR}: \mathrm{S}=38: 1(\mathrm{~F} 1)$ & 88.6 & 2.3 & 9.1 & - \\
\hline PR:S = 38:1 with molasses $(F 1 m)$ & 84.4 & 2.2 & 8.6 & 4.8 \\
\hline PR:S = 10:1 (F2) & 82.7 & 8.2 & 9.1 & - \\
\hline PR:S $=10: 1$ with molasses (F2m) & 78.8 & 7.8 & 8.6 & 4.8 \\
\hline
\end{tabular}

Table 4. Granulation of PRSF and mechanical properties of granules

\begin{tabular}{|l|c|c|c|c|}
\hline \multirow{2}{*}{ Properties } & \multicolumn{4}{|c|}{ Type of fertilizer } \\
\cline { 2 - 5 } & $\mathrm{F} 1$ & $\mathrm{~F} 1 \mathrm{~m}$ & $\mathrm{~F} 2$ & F2m \\
\hline $\begin{array}{l}\text { Grain-size distribution } \\
(\mathrm{mm})\end{array}$ & 2.95 & 2.97 & 4.76 & 4.36 \\
\hline SD & $(0.776)$ & $(0.821)$ & $(0.950)$ & $(0.741)$ \\
\hline Mechanical resistance (N) & 88.2 & 98.0 & 25.8 & 15.3 \\
\hline SD & $(13.1)$ & $(11.1)$ & $(7.56)$ & $(3.74)$ \\
\hline
\end{tabular}

Table 5. Chemical composition of PRSF

\begin{tabular}{|l|c|c|c|c|}
\hline \multirow{2}{*}{ Element } & \multicolumn{4}{|c|}{ Content (\% mass) } \\
\cline { 2 - 5 } & F1 & F1m & F2 & 10.70 \\
\hline Total P in mineral acids & 11.50 & 11.10 & 6.31 & 10.10 \\
\hline P soluble in 2\% formic acid & 5.40 & 5.53 & 3.57 & 6.07 \\
\hline P soluble in 2 \% citric acid & 3.01 & 3.07 & 1.81 & 3.34 \\
\hline P soluble in ammonium citrate $(\mathrm{pH} 7.0)$ & 1.24 & 1.27 & 0.042 & 1.77 \\
\hline P soluble in water & 0.041 & 0.042 & 34.2 & 3.042 \\
\hline Ca & 34.26 & 33.55 & 8.5 & 8.10 \\
\hline S & 2.60 & 2.50 & 8.50 & \\
\hline
\end{tabular}




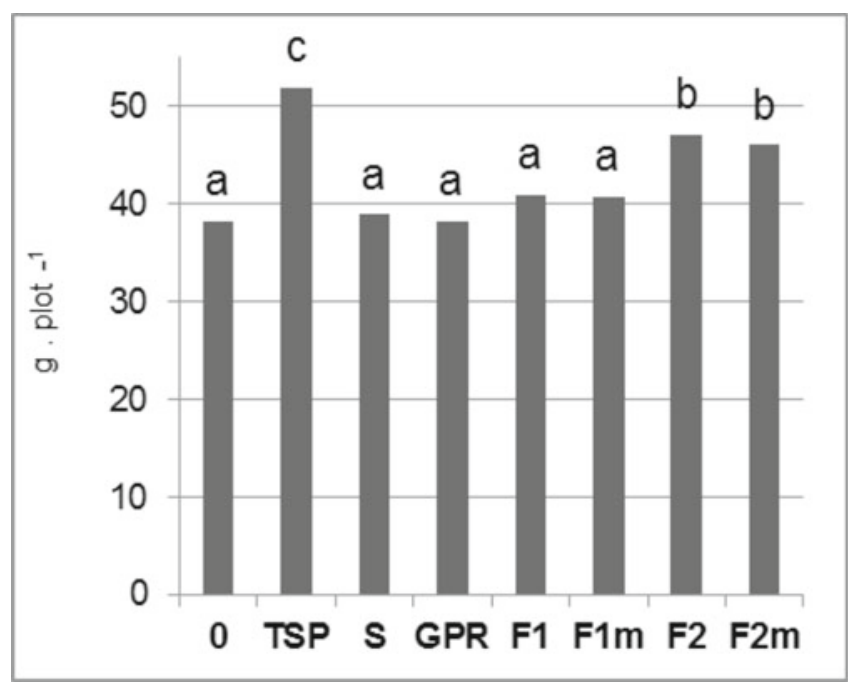

Figure 1. Oat grain yield. The same letters stand for no significant differences between treatments by Tukey's test $(\mathrm{P}<0.05)$

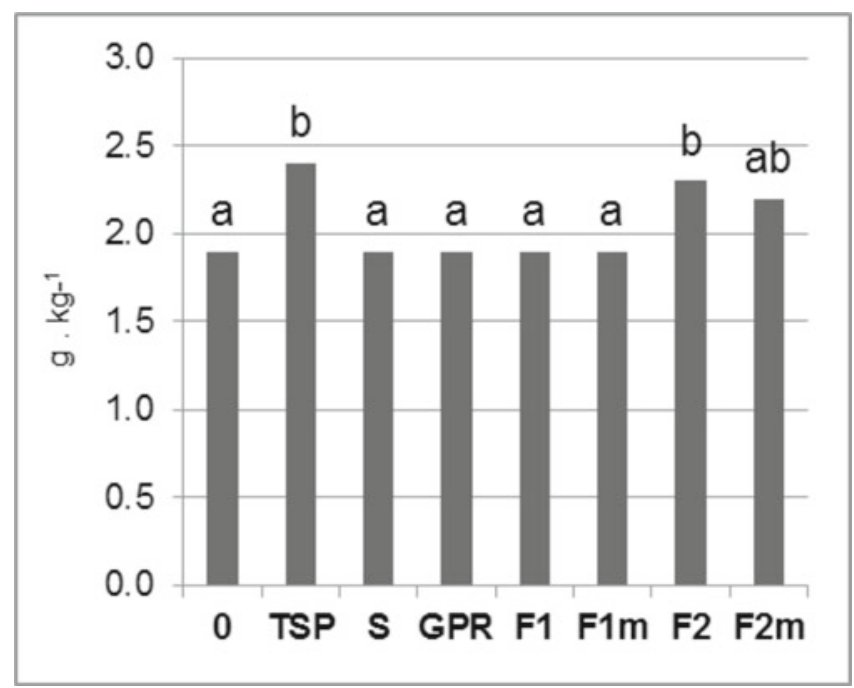

Figure 2. Concentration of $\mathrm{P}$ in oat grain. The same letters stand for no significant differences between treatments by Tukey's test $(\mathrm{P}<0.05)$

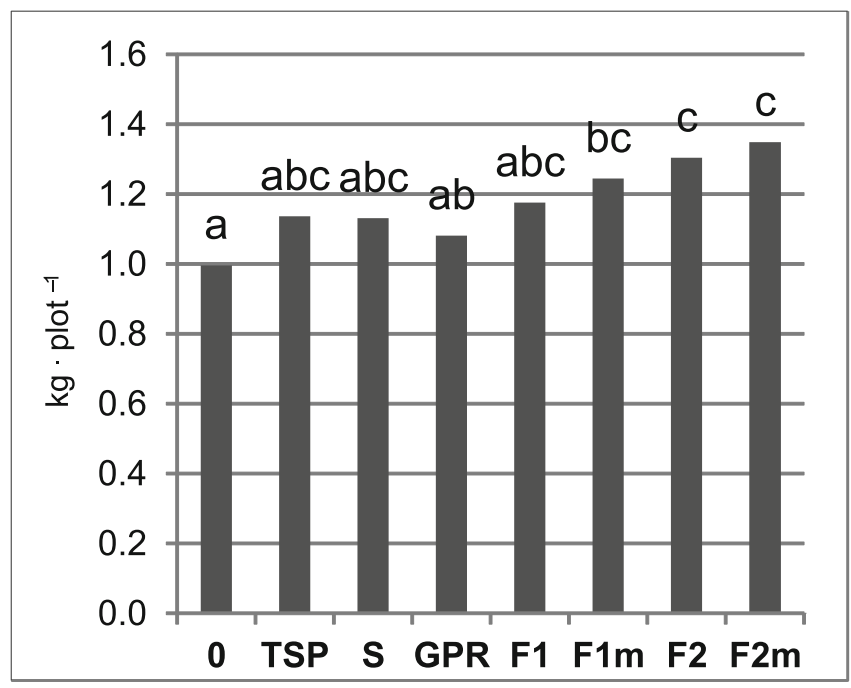

Figure 3. Maize grain yield. The same letters stand for no significant differences between treatments by Tukey's test $(\mathrm{P}<0.05)$

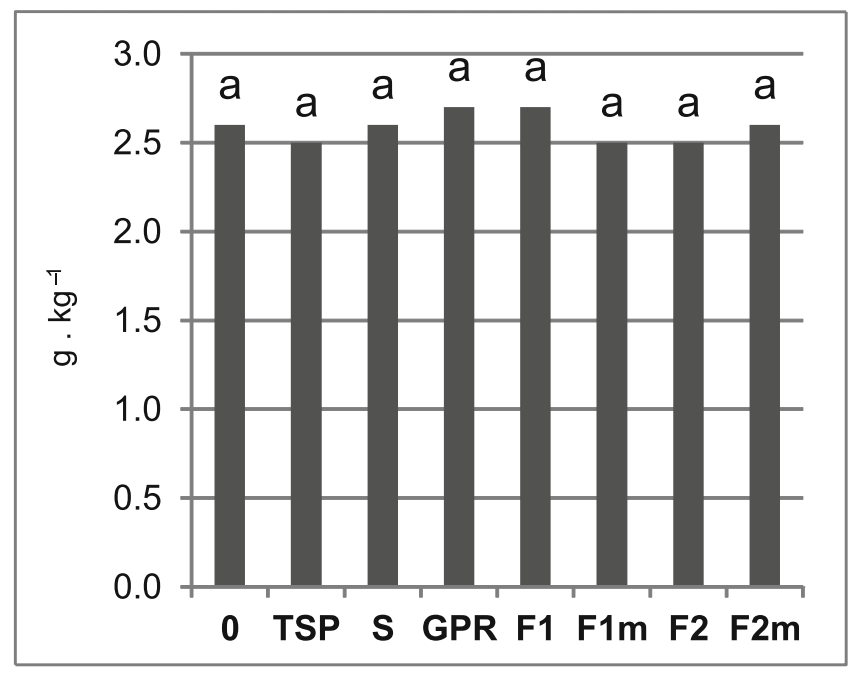

Figure 4. Concentration of phosphorus in maize ear leaf. The same letters stand for no significant differences between treatments by Tukey's test $(\mathrm{P}<0.05)$

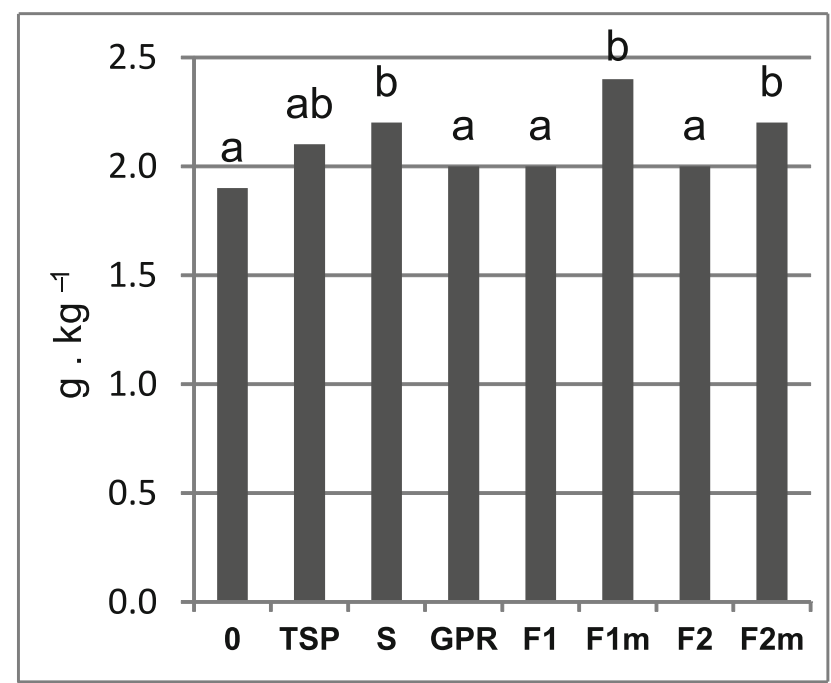

Figure 5. Concentration of sulphur in maize ear leaf. The same letters stand for no significant differences between treatments by Tukey's test $(\mathrm{P}<0.05)$

On neutral soil with a relatively high content of organic carbon, maize responded to F2 by producing a significantly higher grain yield than on the GPR fertilized treatment (Fig. 3). It was also observed the insignificant tendency to produce higher yield at F1 treatment in comparison to the GPR. In contrast to slightly acid soil, the yield-stimulating influence of phosphate and sulphur fertilizers on neutral soil was not inferior to that generated by TSP. Despite the determined difference in maize yields (Fig. 3), the concentration of phosphorus in maize leaf was similar on all treatments (Fig. 4). However, important differences in the content of sulphur were observed (Fig. 5). Fertilizers with molasses (F1m and F2m), as well as using only sulphur ( $\mathrm{S})$, caused an increase in the content of this component in the leaf compared to the other treatments. However, these contents did not exceed the value of $5 \mathrm{~g} \cdot \mathrm{kg}^{-1}$, which is the upper limit of the optimal range ${ }^{21}$.

Based on the yields of crops as well as the concentration of phosphorus in plants, it has been found out that on either soil PRSF with molasses were not more effective than the fertilizers without molasses. 
The positive effect of added elemental sulphur to GPR on release of plant accessible forms of phosphorus has also been demonstrated in another research ${ }^{15-17}$. Owing to PRSF, higher yields of crops were obtained than in the treatment enriched with GPR. The increase in yields depended on the amount of added sulphur, phosphate granulation, time elapsing from fertilizer application and crop species. The best results were attained when the phosphate rock to sulphur ratio was 14:1-10:1. A higher share of sulphur often caused negative effects on plants and the environment.

\section{CONCLUSIONS}

Plant availability of phosphorus derived from ground phosphate rock was not satisfactory.

Sulphur added to phosphate rock in a ratio of $1: 10$ as well as granulation of both components improved the phytoavailability of phosphorus, thus ensuring better yields.

Addition of molasses to PRSF did not improve their fertilization effectiveness.

Granulation of a mixture of phosphate rock and sulphur by compaction is possible on a pelleting press but not on a roll press.

\section{ACKNOWLEDGMENTS}

This study has been performed as part of the research project no NR14-0075-10/2010 founded by the National Centre for Research and Development (NCBiR)

\section{LITERATURE CITED}

1. Zapata, F. \& Roy, R.N. (2004). Use of phosphate rocks for sustainable agriculture. FAO Fert. Plant Nutr. Bul. 13. Food and Agriculture Organization of the United Nations, Rome.

2. Stockdale, E.A., Watson, C.A. \& Edwards, A.C. (2006). Phosphate rock: Using biological processes to increase its effectiveness as a fertiliser. International Fertiliser Society Proceedings 592, York UK. pp. 24.

3. Vassilev, N. \& Vassileva, M. (2003). Biotechnological solubilization of rock phosphate on media containing agro-industrial wastes. Microbiol. Biotechnol. 61, 435-440. DOI: 10.1007/s00253-003-1318-3.

4. Korzeniowska, J. \& Stanisławska-Glubiak, E. (2011). New trends in using rock phosphates in agriculture. Post. Nauk Rol. 3, 57-66 (in Polish).

5. Skut, J., Hoffmann, K. \& Hoffmann, J. (2012). Temperature and moisture influence on the curing process of PAPR-type fertilizer products. Pol. J. Chem. Tech. 14, 77-82. DOI: 10.2478/v10026-012-0088-z.

6. Rajan, S.S.S. (1983). Effect of sulphur content of phosphate rock/sulphur granules on the availability of phosphate to plants. Fert. Res. 4, 287-296.

7. Evans, J., McDonald, L. \& Price, A. (2006). Application of reactive phosphate rock and sulphur fertilisers to enhance the availability of soil phosphate in organic farming. Nutr. Cycl. Agroecosyst. 75, 233-246. DOI: 10.1007/s10705-006-9030-1.

8. Evans, J. \& Price, A. (2009). Influence of rates of reactive phosphate rock and sulphur on potentially available phosphorous in organically managed soils in the south-eastern near-Mediterranean cropping region of Australia. Nutr. Cycl. Agroecosyst. 84, 105-118. DOI: 10.1007/s10705-008-9230-y.

9. Stamford, N.P., Santos, P.R., Santos, C.E.S., Freitas, A.D.S., Dias, S.H.L. \& Lira, Jr., M.A. (2007). Agronomic effectiveness of biofertilizers with phosphate rock, sulphur and Acidithiobacillus for yam bean grown on Brazilian tableland acidic soil. Bioresour. Technol. 98, 1311-1318.
10. Hoffmann, J., Korzeniowska, J., Stanisławska-Glubiak, E. \& Hoffmann, K. (2012). Increasing efficiency of phosphate rock by sulfur addition. Part 1 . Technological issues regarding manufacturing of phosphate rock-sulfur fertilizers. Przem. Chem. 5, 745-748 (in Polish).

11. Singh, C.P. \& Amberger, A. (1991). Solubilization and availability of phosphorus during decomposition of rock phosphate enriched straw and urine. Bio. Ag. Hort. 7, 261-269.

12. Polish Standard PN-M-94008.

13. Polish Standard PN-C-04501:1971.

14. Regulation (EC) No 2003/2003 of the European Parliament and of the Council of 13 October 2003 relating to fertilizers (Text with EEA relevance), Official Journal of the European Union, L 304, 122.

15. Korzeniowska, J., Stanisławska-Glubiak, E., Hoffmann, J. \& Igras, J. (2012). Increasing the efficiency of phosphate rock by sulfur addition. Part 3. Agronomic assessment of phosphate-sulfur fertilizers by using plant indicators. Przem. Chem. 5, 796-800 (in Polish).

16. Stanisławska-Glubiak, E., Korzeniowska, J., Hoffmann, J. \& Kantek, K. (2012). Increasing the efficiency of phosphate rock by sulfur addition. Part 2. The impact of phosphate-sulfur fertilizers on the environment. Przem. Chem. 5, 1000-1005 (in Polish).

17. Stanisławska-Glubiak, E., Korzeniowska, J. \& Hoffmann, J. (2012). Increasing efficiency of phosphate rock by sulfur addition. Part 4. Impact of sulfur addition on concentration of microelements in plants. Przem.Chem., 91, 1006-1009 (in Polish).

18. Hignett, T. (1967). Fertilizer Manual. Muscle Shoals, USA: International Fertilizer Development Center.

19. Ghosal, P.K. \& Chakraborty, T. (2012). Comparative Solubility Study of Four Phosphatic Fertilizers in Different Solvents and the Effect of Soil. Res. Environ. 2(4), 175-179. DOI: $10.5923 /$ j.re.20120204.07.

20. Asomaning, S.K., Abekoe, M.K. \& Owusu-Bennoah, E. (2006). Phosphate rock dissolution and availability in some soils of semi-deciduous rainforest zone of Ghana, West Afr. J. Appl. Ecol. 10(1).

21. Jones, J.B.Jr, Wolf, B. \& Mills, H.A. (1991). Plant analysis handbook. Micro-Macro. Publishing Inc. Athens, Georgia, USA. 